\title{
MORALITAS DALAM NOVEL PARA PRIYAYI KARYA UMAR KAYAM MORALITY IN UMAR KAYAM'S NOVEL PARA PRIYAYI Lustantini Septiningsih
}

\author{
Pusat Pengembangan dan Pembinaan, Kementerian Pendidikan dan Kebudayaan
}

Pos-el: lustantini@yahoo.com

\begin{abstract}
ABSTRAK
Novel merupakan media yang dapat menjadi sarana untuk menyampaikan nilai moral kehidupan. Nilai moral dimaksudkan untuk menerangkan apa yang seharusnya dan tidak seharusnya dilakukan manusia terhadap manusia lain. Dari nilai itulah muncul moralitas. Novel Para Priyayi karya Umar Kayam dapat digali dari aspek moralitasnya. Penelitian ini bertujuan mendiskripsikan moralitas dalam novel Para Priyayi karya Umar Kayam. Penelitian ini termasuk penelitian kualitatif. Metode yang digunakan dalam penelitian adalah metode deskriptif, yaitu penelitian dilakukan atas dasar fakta yang ada. Untuk mengetahui moralitas yang terkandung dalam novel Para Priyayi digunakan pendekatan sosiologi sastra, yaitu pendekatan sastra yang mengungkapkan aspek moralitas dalam karya sastra. Hasil penelitian menunjukkan bahwa dalam novel Para Priyayi terkandung moralitas yang meliputi moralitas sebagai kepala keluarga, moralitas sebagai guru, moralitas sebagai pemangku budaya, dan moralitas sebagai seorang yang sukses. Moralitas yang dilukiskan itu merupakan nilai atau ajaran yang disampaikan oleh pengarang.
\end{abstract}

Kata Kunci: moralitas, sosiologi sastra, deskriptif, nilai

ABSTRACT

Novel is a medium that can be a means to convey the moral values of life. Moral values is intended to explain what man should and should not do to other human beings. From that values comes morality. Umar Kayam's novel Para Priyayi can be extracted from the aspect of his morality. This study aims to describe morality in Umar Kayam's novel Para Priyayi. This research includes qualitative research. The method used in this research is descriptive method, that is research conducted on the basis of existing facts. To know the morality contained in the novel Para Priyayi used the approach of literary sociology, the literary approach that expresses the aspect of morality in the literary work. The results show that in the novel Para Priyayi contained morality that includes morality as head of the family, morality as a teacher, morality as a cultural bearer, and morality as a success. The depicted morality is the value or teaching conveyed by the author.

Key Words: morality, sociology of literature, descriptive, value

\section{PENDAHULUAN}

Dalam kehidupan di dunia ini, manusia dituntut untuk dapat bekerja sama dengan manusia lainnya. Hal itu disebabkan manusia selain sebagai makhluk individu, ia juga sebagai makhluk sosial. Namun, tidak jarang manusia dapat diajak bekerja sama. Akal dan pikiran serta perasaan dan kehendak nanusia akan melahirkan tindakan (sikap dan perilaku) sesuai dengan keinginannya 
masing-masing. Ada tindakan yang sesuai dengan norma. Sebaliknya, ada tindakan yang tidak sesuai dengan norma. Apabila yang dilakukan seseorang itu sesuai dengan nilai atau norma yang berlaku di masyarakat dan dapat diterima serta menyenangkan lingkungan masyarakat, orang itu memiliki moral yang baik. Sebaliknya, apabila yang dilakukan seseorang itu tidak sesuai dengan nilai atau norma yang berlaku di masyarakat dan tidak dapat diterima serta tidak menyenangkan lingkungan masyarakat, orang itu memiliki moral yang tidak baik.

Moral dalam karya sastra biasanya mencerminkan pandangan hidup pengarang dan pandangannya tentang nilai kebenaran yang ingin disampaikan kepada pembaca. Karya sastra, seperti novel, merupakan media yang dapat menjadi sarana untuk menyampaikan nilai moral atau yang bersifat mendidik. Nilai itu merupakan petunjuk yang sengaja diberikan oleh pengarang tentang berbagai hal yang berhubungan dengan kehidupan, seperti sikap, tingkah laku, dan sopan santun pergaulan (Nurgiantoro, 2005:321). Selain itu, moral dalam karya sastra merupakan suatu saran yang berhubungan dengan ajaran moral tertentu yang bersifat praktis yang dapat diambil dan ditafsirkan oleh pembaca melalui cerita. Menurut Pradopo (1984:180), ajaran moral diungkapkan pengarang dalam karya sastra karena karya sastra merupakan media untuk mencapai tujuan tertentu, minimal bagi pembacanya.

Poejowijanto (1990:43) mengemukakan bahwa ajaran moral juga dianggap menjadi ukuran baik dan buruk dan menjelaskan apa yang seharusnya dilakukan oleh manusia dengan manusia lainnya sesuai dengan aturan yang berlaku. Oleh karena itu, langsung atau tidak langsung karya sastra mengandung sesuatu yang disebut amanat atau moral yang mampu membangkitkan religiusitas pembaca (Darma, 1984:79). Sastra juga dapat difungsikan sebagai pembina tata nilai dalam kehidupan yang berkaitan dengan tujuan pendidikan humaniora, yaitu membentuk manusia yang berbudi, berbudaya, dan berkarakter. Oleh karena itu, karya sastra yang baik akan mampu memberikan kesenangan (estetika) dan nilai (etika) (Fananie, 2003:113).

Dalam novel Para Priyayi karya Umar Kayam, gambaran tentang moralitas dapat ditemukan melalui perilaku tokohnya dalam keterlibatannya dengan berbagai peristiwa. Umar Kayam dalam novel itu melukiskan perjuangan Soedarsono untuk menjadi seorang priayi. Kesuksesan Sastrodarsono menjadi priayi menjadikan kehidupannya berbeda dengan kehidupan sebelumnya karena ia harus hidup dengan perilaku kehidupan priayi, seperti berbudi halus serta bertingkah laku halus, sopan, lembut, dan beradab. Sastrodarsono berusaha menjaga perilakunya tersebut agar dapat menjadi teladan bagi anak-anaknya.

Tulisan ini menyajikan analisis moralitas novel Para Priyayi yang terkandung di dalamnya. Analisis didasarkan pada pandangan yang menyebutkan bahwa dalam karya sastra dapat ditemukan pesan moral yang dapat diangkat dan bermanfaat bagi kehidupan manusia. Menurut pengamatan penulis, penelitian terhadap Para Priyayi sudah banyak dilakukan, baik dari aspek intrinsik maupun ekstrinsiknya. Penelitian yang dilakukan Sumarno (1993) dalam judul "Novel Multidemensional (Para Priyayai)" menitikberatkan pada keberagaman etnik yang terdapat dalam novel itu. Ekosiswanto (2013) meneliti tentang priayi dengan judul "Pergeseran Makna Priayi dalam Novel Para Priyayi Karya Umar Kayam". Dalam tulisan itu dijelaskan perjalanan kepriayian Sastrodarsono dalam tiga zaman, yaitu zaman Belanda, Jepang, dan Orde Baru, dan perbedaan pandangan dari tokoh-tokohnya mengenai konsep priayi. Selain itu, Septiningsih (1996) dalam penelitiannya yang berjudul "Pemakaian Bahasa dalam Novel Umar Kayam: Tinajaun Stilistika" memfokuskan penelitian pada aspek stilistika. Dalam penelitian itu dianalisis penggunaan bahasa yang dipengaruhi oleh budaya Jawa. Oleh karena itu, untuk melengkapi penelitian dari aspek lain, yaitu moralitas, perlu dilakukan penelitian mengenai 
moralitas yang terkandung dalam karya sastra Indonesia, khususnya dalam novel Para Priyayi karya Umar Kayam.

\section{Rumusan Masalah}

Masalah yang menjadi perhatian utama peneliti adalah masalah moralitas dalam Para Priyayi karya Umar Kayam. Karena moralitas itu berkaitan dengan perilaku tokoh, baik sebagai individu maupun makhluk sosial, rumusan masalah dalam penelitian ini adalah moralitas seperti apa yang dilukiskan pengarang dalam novel Para Priyayi dan bagaimana moralitas itu diwujudkan melalui tokoh utama novel tersebut. Penelitian ini akan menjawab pertanyaan tersebut dengan menganalisis moralitas yang menonjol dari tokoh utama novel Para Priyayi.

\section{Tujuan Penelitian}

Penelitian ini bertujuan mendiskripsikan moralitas yang diwujudkan melalui perilaku tokoh utama dalam novel Para Priyayi serta menganalisisnya. Dengan menganalisis moralitas, diharapkan akan diperoleh gambaran objektif tentang moralitas dalam novel Para Priyayi karya Umar Kayam. Dengan demikian, hasilnya dapat menjawab masalah yang dikemukakan.

\section{Landasan Teori}

Penelitian terhadap karya sastra dapat dilakukan dari berbagai pendekatan, seperti sosiologi sastra, psikologi sastra, antropologi sastra, dan pragmatik. Penelitian ini akan mengungkapkan moralitas dalam novel Para Priyayi. Moralitas dalam karya sastra merupakan unsur ekstrinsik karya sastra. Oleh karena itu, teori yang digunakan sebagai landasan penelitian ini adalah sosiologi sastra. Dasar pendekatan ini adalah bahwa karya sastra tidak dapat lepas dari fakta sejarah dan sosial budaya (Teeuw, 1983:2). Karya sastra tidak dapat dipahami secara lengkap jika dipisahkan dari lingkungan atau kebudayaan yang menghasilkannya. Oleh karena itu, karya sastra harus dipelajari dalam konteks yang lebih luas dan tidak dalam dirinya sendiri (Grebstein dalam Damono, 1984:4).

Dalam Kamus Besar Bahasa Indonesia (Tim Penyusun Kamus, 2008:1332) disebutkan sosiologi sastra adalah sastra yang mengungkapkan pengarang yang dipengaruhi oleh status lapisan masyarakat tempat ia berasal, ideologi politik dan sosialnya, kondisi ekonomi, serta khalayak yang ditujunya. Abrams (1981:178) mengatakan bahwa sosiologi sastra dikenakan pada karya sastra yang utama ditujukan pada cara-cara seorang pengarang dipengaruhi oleh status kelasnya, ideologi masyarakat, keadaan ekonomi yang berhubungan dengan pekerjaannya, dan jenis pembaca yang ditujunya. Jadi, dalam pendekatan sosiologi sastra didasarkan pada hubungan antara sastra dan masyarakat. Menurut Ratna (2008:61), hubungan itu disebabkan oleh (1) karya sastra dihasilkan oleh pengarang, (2) pengarang adalah (anggota) masyarakat, (3) pengarang memanfaatkan kekayaan yang ada dalam masyarakat, dan (4) hasil karya sastra itu dimanfaatkan oleh masyarakat.

Junus (1986:1) mengemukakan tiga pendekatan sosiologi sastra, yaitu (1) pendekatan yang memandang karya sastra sebagai dokumen sosio budaya, (2) pendekatan yang memandang kedudukan sosial pengarang, dan (3) pendekatan yang menekankan pada resepsi masyarakat terhadap suatu karya pengarang tertentu. Hal yang sama dikemukakan oleh Wellek (1989:84) bahwa pendekatan sosiologi sastra mencakupi (1) sosiologi pengarang, yang mempermasalahkan 
pengarang sebagai pencipta karya sasta, (2) sosiologi karya sastra, yang bertitik tolak dari karya sastra, dan (3) sosiologi sastra, yang mempermasalahkan pembaca dan pengaruh sosial karya sastra. Dari pandangan tersebut, pada dasarnya sosiologi dan sastra saling melengkapi karena objeknya sama, yaitu manusia dan masyarakat (Damono, 1984:9)

Moralitas adalah sifat moral atau keseluruhan asas dan nilai yang berkenaan dengan baik dan buruk (Bertens, 2002:7). Moralitas berperan sebagai pengatur dan petunjuk bagi manusia dalam berperilaku agar dapat dikategorikan sebagai manusia yang baik dan dapat menghindari perilaku yang buruk (Keraf, 1993: 20). Dengan demikian, moralitas mengacu pada nilai yang memiliki takaran kualitatif, seperti baik-buruk, benar-salah, wajar-tidak wajar, dan pantas-tidak pantas (Suyanto, 2007:1). Di samping itu, moralitas memberi kepastian tentang halhal apa yang harus dilakukan dan apa yang tidak boleh dilakukan sehingga moralitas dapat dijadikan ukuran untuk menentukan kualitas moral seseorang (Solomon, 1987:13). Berkaitan dengan kualitas moral, Velazquez (2005:9-10) memberikan lima ciri untuk menentukan standar moral sebagai berikut:

1. standar moral yang berkaitan dengan persoalan yang dianggap akan merugikan atau menguntungkan manusia, misalnya perlawanan terhadap pencurian, pemerkosaan, perbudakan, pembunuhan, dan pelanggaran hukum;

2. standar moral yang ditetapkan atau diubah oleh keputusan dewan otoritatif tertentu, tetapi validitas standar moral terletak pada kecukupan nalar yang digunakan untuk mendukung dan membenarkannya;

3. standar moral yang harus lebih diutamakan daripada nilai lain, termasuk kepentingan diri, misalnya ketika lebih memilih menolong orang yang jatuh di jalan daripada ingin cepat sampai tempat tujuan tanpa menolong orang tersebut;

4. standar moral yang berdasarkan pertimbangan yang tidak memihak, yaitu pertimbangan yang dilakukan bukan berdasarkan keuntungan atau kerugian pihak tertentu, melainkan berdasarkan ketentuan bahwa setiap pihak memiliki nilai yang sama; dan

5. standar moral yang diasosiasikan dengan emosi tertentu dan kosakata tertentu. Emosi yang mengasumsikan adanya standar moral adalah perasaan bersalah, sedangkan kosakata atau ungkapan yang merepresentasikan adanya standar moral adalah "ini salah saya", "saya menyesal", dan sejenisnya.

Sementara itu, Suseno (dalam Djojosuroto, 2006:12) mengemukakan tiga tolok ukur prinsip dasar moral, yaitu prinsip baik, keadailan, dan hormat terhadap diri sendiri. Dari tolok ukur standar moral tersebut, dapat ditentukan seseorang bermoral atau tidak bermoral dari perilakunya. Apabila perilakunya berlawanan dengan standar moralitas yang berlaku, seseorang dianggap tidak bermoral, begitu pula sebaliknya.

Moralitas dalam sastra adalah nilai-nilai yang dijalani atau dilaksanakan tokoh dalam kehidupan. Nilai itu diwujudkan dalam perilaku tokoh yang dilukiskan dalam berbagai peristiwa. Dari nilai-nilai itu dapat diketahui moralitas tokoh dalam karya sastra.

\section{METODE DAN TEKNIK}

Penelitian ini merupakan penelitian kualitatif, yaitu penelitian yang menghasilkan data deskriptif berupa kata-kata, dengan menggunakan novel sebagai data yang dianalisis. Sumber data penelitian ini adalah sebuah teks karya sastra berupa novel yang berjudul Para Priyayai karya Umar Kayam (1990). Metode yang digunakan dalam penelitian ini metode deskriptif, yaitu metode penelitian yang berdasarkan data dalam novel Para Priyayai. Oleh karena itu, dalam metode tersebut dituntut persyaratan bahwa suatu penelitian harus dilakukan atas dasar fakta 
seperti dikemukakan oleh Nawawi (2012:68) bahwa ciri metode deskriptif adalah memusatkan perhatian pada masalah yang diselidiki dan menggambarkan fakta tentang masalah yang diselidiki.

Sumber data penelitian ini adalah novel Para Priyayai karya Umar Kayam (1990). Teknik pengumpulan data dalam penelitian ini dilakukan dengan teknik studi pustaka. Penelitian yang berdasarkan data dari novel yang berjudul Priyayai menghasilkan data deskriptif yang berupa data tertulis. Data tersebut dianalisis untuk mengetahui moralitas dalam novel Para Priyayi. Teknik analisis data yang digunakan adalah teknik analisis isi teks.

\section{PEMBAHASAN}

Dalam novel Para Priyayi moralitas dilukiskan melalui tokoh-tokohnya. Penelitian ini memfokuskan pada moralitas tokoh utamanya, yaitu Sastrodarsono. Moralitas yang terkandung dalam Para Priyaya adalah moralitas sebagai kepala keluarga, moralitas sebagai guru (pendidik), moralitas sebagai pemangku budaya, dan moralitas sebagai orang yang sukses.

\section{Moralitas sebagai Kepala Keluarga}

Seorang kepala keluarga, apakah itu ayah atau ibu, merupakan pemimpin dalam rumah tangga atau keluarga. Mereka mempunyai tanggung jawab mendidik, mengasuh, dan membimbing anak-anak mereka untuk mencapai tahapan tertentu yang mengantarkan mereka untuk siap dalam kehidupan bermasyarakat. Jika tanggung jawab itu terabaikan, anak mereka juga yang menjadi korban. Dengan demikian, tidak jarang seorang anak yang sukses atau yang gagal yang dijadikan penyebabnya adalah orang tuanya.

Moralitas kepala keluarga dalam Para Priyayi terungkap melalui perilaku Sastrodarsono sebagai kepala keluarga dalam mendidik anak-anaknya. Ia sebagai kepala keluarga di dalam rumah tangga menerapkan prinsip menjunjung nilai moral agar menjadi anutan anakanaknya. Menjunjung moral yang dilakukannya ditunjukkan dengan bersikap mendidik, mengasuh, dan membimbing anak-anaknya.

Dalam Para Priyayi, Sastrodarsono merupakan kepala keluarga dari tiga orang anak, yaitu Noegroho, Hardojo, dan Soemini. Istrinya bernama Siti Aisah. Dalam mendidik anakanaknya, Sastrodarsono berusaha menjadikan anak-anaknya sukses dalam bidang pendidikan. Sastrodarsono memandang bahwa pendidikan itu penting karena dapat meneruskan kepriayiannya. Dengan pendidikan, anak-anaknya juga dapat memberikan pengabdiannya kepada bangsanya. Untuk itu, semua anaknya disekolahkan di sekolah priayi (HIS), seperti dilukiskan sebagai berikut.

Anak-anak kami, kami masukkan ke sekolah HIS, sekolah dasar untuk anak-anak priayi itu, karena sekolah ini diadakan untuk menyiapkan priayi-priayi gupermen. Anak-anak bersekolah di situ akan diajar bahasa Belanda, bahasa yang sangat penting buat mendapat kedudukan di kantor gupermen dan dapat meneruskan pelajaran ke sekolah menengah dan sekolah menengah atas priayi, seperti Mulo, AMS, atau sekolah-sekolah menengah guru, seperti Normaal, Kweeksekul, dan sebagainya. (Kayam, 1990: 52)

Dari pendidikan tersebut, anak-anak Sastrodarsono sukses dalam pengabdiannya di masyarakat melalui keahlian dan pekerjaan masing-masing. Noegroho, misalnya, pekerjaannya adalah sebagai guru HIS Negeri di Yogyakarta. Pada saat kedatangan Jepang di Indonesia, Noegroho berganti pekerjaan menjadi prajurit. Setelah pengakuan kedaulatan negara Republik Indonesia, Noegroho pindah di Jakarta. Ia di Jakarta diangkat menjadi Dirjen Kementerian Perdagangan. 
Perilaku yang baik dalam bekerja, seperti menyukai pekerjaan dan memajukan anak Indonesia, juga ditanamkan oleh Sastrodarsono dalam mendidik anak-anaknya. Didikan Sastrodarsono itu dipraktikkan oleh Hardojo. Sebagai guru, ia bekerja dengan baik. Atas prestasinya itu, Hardojo diminta oleh Gusti Pangeran Adipati Arya Mangkunegara VII menjadi guru di Mangkunegaran, Solo. Prestasi atas pekerjaan Hardojo dilukiskan sebagai berikut.

"Lho, Dimas Hardojo, Anda selalu kami amati. Menurut penglihatan saya, Anda mempunyai bakat organisasi dan mendidik yang baik sekali. Anda suka berolahraga, bertamasya, dan berkemah dengan murid-murid. Anda juga suka kesenian dan mampu juga menarik muda-mudi untuk ikut tertarik pada kesenian." (Kayam, 1990:55)

Tawaran Gusti Pangeran itu diterima Hardojo meskipun gaji yang diberikannya kecil.Perilaku Hardojo seperti itu didasari atas semangatnya yang ingin mengabdi kepada bangsanya untuk memajukan anak Indonesia melalui pendidikan.

Sastrodarsono juga berhasil dalam mendidik anak perempuannya, yaitu Soemini. Setelah tamat HIS, Soemini tidak mau menikah. Ia mempunyai pemikiran yang maju, seperti dilukiskan sebagai berikut.

"Pertimbangan saya, Bu, Pak. Saya merasa belum siap. Kalau tamat HIS ini nanti saya baru akan lima belas tahun umur saya. Bukankah kita termasuk keluarga priayi maju pengikut pikiran Raden Ajeng Kartini yang tidak setuju kawin terlalu muda. Juga saya masih ingin menambah pengetahuan dan ingin merasakan sekolah di kota yang lebih besar dari Wanagalih. Sekolah ke Solo atau ke mana begitu." (Kayam, 1990:7)

Pemikiran Soemini yang maju itu membentuk dirinya menjadi wanita yang pandai dan aktif dalam berbagai organisasi di masyarakat.

Tanggung jawab pendidikan yang ditekankan oleh Sastrodarsono tidak terbatas kepada anaknya. Anak angkatnya, Lantip, juga dididik seperti anaknya sendiri. Ia juga disekolahkan di sekolah anak-anak priayi (HIS). Akhirnya, ia menjadi sarjana Universitas Gadjah Mada. Perilaku Sastrodarsono sebagai kepala keluarga yang memperhatikan anak angkat menjadikan Lantip sebagai anak angkat berperilaku bijaksana. Hal itu ditunjukkan jika Sastrodarsono memarahi Lantip dengan sebutan anak maling atau anak rampok, Lantip tidak sakit hati. Ia tetap melihat Sastrodarsono dari sisi positifnya karena ia memahami bahwa dirinya diangkat sebagai anak Sastrodarsono merupakan suatu kebahagiaan, seperti dikemukakan berikut ini.

Umpatanmu yang sekali-kali kaulontarkan, "anak maling, perampok, gerombolan kecu" tidak akan mungkin menyakiti hati saya. Bahkan, sebaliknya akan memperkukuh semangat saya untuk menjunjung keluarga Sastrodarsono. Mikul duwur mendem jero, menjunjung tinggi-tinggi keharuman nama keluarga, menanam dalam-dalam aib keluarga. (Kayam, 1990:123)

Terhadap anak-anaknya, Sastrodarsono selalu bersikap sama, tidak pilih kasih, demi menjaga kerukunan mereka. Nilai kerukunan itu ditanamkan dengan melibatkan anak-anaknya apabila nempunyai masalah keluarga. Keterlibatan mereka itu diharapkan dapat mempunyai rasa empati. Rasa empati itu akan menumbuhkan perilaku mereka akan rasa saling menyayangi. Rasa saling menyayangi itu penting untuk ditanamkan karena akan mewujudkan hidup rukun. Sastrodarsono juga memberikan contoh kerukunan saat menghadapi masalah anak perempuannya, Soemini, menolak untuk menikah dengan Harjono karena masih ingin bersekolah. Padahal, lamaran Harjono sudah diterima oleh Sastrodarsono. 
Untuk memecahkan masalah tersebut, Sastrodarsono memanggil anak-anaknya. Mereka dimintai pendapatnya. Sastrodarsono juga tidak bersikap otoroter. Ia juga menekankan nilai musyawarah. Dengan demikiaan, saat anak-anaknya mendukung pilihan Soemini, yaitu menunda pernikahan dengan Harjono, Sastrodarsobno pun menerimanya. Untuk itu, ia memutuskan tidak segera menikahkan Soemini dengan Harjono karena Soemini akan nelanjutkan sekolah.

Dalam peristiwa lain, saat Hardojo akan menikah dengan pacarnya yang beragama Katolik, Sastrodarsono dan saudara-saudara Hardojo tidak menyetujui pernikahan mereka. Hardojo memahami putusan mereka. Jika Hardojo tetap melanjutkan nenikah dengan pacarnya tersebut, Hardojo memastikan dirinya akan dijauhi oleh keluarganya. Untuk itu, Hardojo tidak jadi menikah dengan pacarnya yang Katolik, seperti dilukiskan sebagai berikut.

Wah, kemungkinan ini di luar perhitungan saya. Perkawinan tidak di depan penghulu dan tidak di depan gereja? Edan! Apa mungkin itu? Siapa yang mesti memberi donga, doa, dan berkat. Saya sudah hampir mengatakan bahwa hal itu tidak mungkin saya terima. (Kayam, 1990:98)

Sikap Hardojo itu juga menunjukkan bahwa ia tidak mau mementingkan dirinya sendiri. Dengan demikian, kerukunan dalam keluarga tetap terjaga.

Kerukunan keluarga Sasatrodarsono yang lain dilukiskan dengan seringnya anak-anak Sastrodarsono mengunjungi orang tuanya meskipun nereka sudah berkeluarga dan bekerja, atau bahkan mempunyai jabatan, seperti dilukiskan sebagai berikut.

Saya memenuhi janji saya untuk sowan ke Wanagalih sesudah menjalani latihan di Bogor. Saya datang dengan seluruh keluarga saya. Demikian juga dengan adik-adik saya yang juga datang bersama keluarga mereka. Alangkah rukun dan guyub keluarga besar kami sesungguhnya. Pada saat-saat yang kami anggap penting, apalagi yang kami anggap peka, kami selalu berkumpul di Wanagalih. Sudah tentu pusat dari itu semua adalah Bapak dan Ibu. Betapa pun kami sudah menjadi orang, sudah beranak pinak dan memiliki kedudukan di masyarakat .... (Kayam, 1990:180)

Kerukunan yang ditanamkan Sastrodarsono terhadap anak-anaknya menjadikan mereka saling menyayangi antara orang tua dan sauara-saudara. Kerukunan mereka juga menjadikan mereka tetap mencintai kampung halamannya.

\section{Moralitas sebagai Guru (Pendidik)}

Guru merupakan profesi yang terhormat dan memiliki tanggung jawab moral di masyarakat. Proses pembelajaran tidak dapat lepas dari peranan guru. Seseorang yang memiliki profesi sebagai guru dianggap sebagai tokoh masyarakat sehingga guru menjadi anutan masyarakat dalam berperilaku. Dari guru, siswa mendapat pengetahuan baru dan pendidikan karakter. Hal itu membuat tidak sembarang orang dengan begitu saja dapat berperan sebagai guru. Menurut Sardiman (2011:44-146), guru mempunyai peran sebagai informator, oganisator, motivator, pengarah, inisiator, transmiter, fasilitator, mediator, dan evaluator. Karena peranannya yang besar, guru mempunyai tanggung jawab yang cukup berat. Kata guru yang banyak orang dipanjangkan menjadi digugu dan ditiru juga menjadikan guru harus menjaga perilakunya dengan baik. Banyak orang menilai bahwa kesuksesan dan kegagalan siswa dikaitkan dengan peranan seorang guru.

Moralitas guru dalam Para Priyayi dilukiskan melalui tokoh utama, Sastrodarsono, yang berprofesi sebagai guru. Dasar pilihan Sastrodarsono sebagai guru karena ia ingin memajukan anak-anak di desanya. Ia juga bercita-cita sekolah tempat ia mengajar dapat menjadi sekolah 
yang baik agar anak-anak desa dapat melanjutkan pendidikan ke sekolah yang lebih tinggi. Dengan demikian, apabila mencari pekerjaan, mereka tidak mengalami kesulitan.

Selain itu, ia juga menjunjung moral guru yang merupakan bentuk tanggung jawabnya sebagai pendidik. Hal itu ditunjukan dengan keseriusannya dalam mengajar dengan menanamkan disiplin yang tinggi. Hasilnya pun sangat baik. Hal itu ditunjukkan dengan prestasi siswanya yang melebihi prestasi siswa HIS, seperti dilukiskan sebagai berikut.

Di sekolah desa kami diperintahkan untuk sangat menekankan pengajaran kami di bidang-bidang berhitung, menulis, dan bahasa Jawa. Kami diperintahkan untuk sangat keras dan tertib dalam mengajar bidang-bidang tersebut. Maka hasilnya pun kelihatan pada anak-anak desa yang tamat dari sekolah desa. Mereka, pada umumnya, sangat bagus tulisan tangangannya dan pintar berhitung serta baik penguasaan bahasa Jawanya. Sering kali saya bertanya kepada anak-anak tamatan sekolah priayi seperti HIS mengapa tulisannya tidak sebagus anak-anak desa. (Kayam, 1990:53)

Atas prestasinya itu, Satrodarsono diangkat menjadi kepala sekolah untuk menggantikan Mas Martoatmodjo yang dipindahkan ke sekolah Desa Gesing.

Sebagai guru di tempat baru, Sastrodarsono tetap menjaga moralitasnya sebagai guru. Hal itu ditunjukkan dengan perilakunya yang tetap menjaga cara mengajar yang baik, yaitu tetap menerapkan cara mengajarnya seperti yang pernah dilakukannya. Ia juga berprinsip bahwa mengajarnya itu didasari oleh pengabdiannya kepada bangsanya. Dengan demikian, tuntutan pemerintah Jepang agar Sastrodarsono dan siswanya setiap pagi diharuskan menghormat Kaisar Jepang dengan membungkukkan badan ke arah utara ditolaknya. Permintaan pemerintah Jepang tidak sesuai dengan moralitasnya sebagai warga negara yang mencintai negaranya. Sikap Sastrodarsono yang tetap mempertahankan moralitasnya dilakukan dengan memilih pensiun sebagai guru daripada harus memenuhi perintah Jepang. Sebagai risiko penolakannya itu, ia ditempeleng Tuan Sato (Nippon). Bagi Satrodarsono, sikap Nippon itu dianggap sebagai bentuk penghinaan terhadap harga dirinya sehingga ia marah sekali. Namun, sebagai guru yang harus bersikap sabar dalam menyikapi masalah kehidupan, hal itu dapat diatasinya dengan dukungan istrinya, seperti dilukiskan berikut ini.

"Oh, Allah, Bu. Belum pernah saya dihina orang seperti sekarang ini. Dia memukul kepala saya, Bune. Kapala!"

Ndoro Guru Putri cepat menghibur suaminya dan memberi tanda kepada saya untuk mendekat ke kursi goyang. (Kayam, 1990:129—130)

Nilai kesetiaan kepada negara yang telah mengakar dalam diri Sastrodarsono diajarkan, selain kepada siswanya, juga kepada anak-anaknya yang sudah bekerja. Unruk menanamkan nilai kesetiaan kepada negara, Sastrodarsono menggunakan acuan filosofi yang ada dalam pewayangan. Dalam hal itu, ia mengambil contoh tembang "Tripama" yang mengisahkan kesetiaan Sumantri kepada Prabu Arjuna Sasrabahu, kesetiaan Karna kepada Prabu Suyudana, dan kesetiaan Kumbakarna kepada Kerajaan Alengka. Tembang itu dipilih karena filosofi tentang kesetiaan kepada negara tepat sekali untuk menasihati anaknya, Noegroho, yang menjadi prajurit, dan Hardojo yang menjadi guru di Mangkunegaran. Sastrodarsono berharap filosofi kesetiaan dalam pewayangan itu dapat menjadi contoh anak-anaknya dalam mengabdi kepada negara melalui pekerjaan masin-masing, seperti dilukiskan dalam kutipan berikut ini.

Meskipun "Tripama" ini kelihatannya hanya ditujukan untuk para prajurit, sesungguhnya juga dimaksudkan untuk para priyayi semua. Inti dari wejangan itu adalah kesetiaan kepada raja dan negara. 
Kita semua diingatkan untuk meniru sikap setia dari tokoh dalam wayang, yaitu Sumantri, Karna, dan Kumbakarna. Meskipun sifat kesetiaan mereka berbeda, namun intinya sama, yaitu kesetiaan sebagai tanda tahu membalas budi kepada raja dan negara. (Kayam, 1990:185)

\section{Moralitas sebagai Pemangku Budaya}

Priayi merupakan golongan sosial yang terpandang dalam masyarakat Jawa. Mereka merupakan salah satu pihak pemangku budaya Jawa. Hidup sebagai priayi membawa kewajiban menjaga nilai budaya. Sesorang itu digolongkan priayi, antara lain, ditentukan oleh tingkat pendidikan dan kekayaan. Di dalam kehidupan, priayi dihormati dan perilakunya menjadi anutan masyarakat. Oleh karena itu, dalam kehidupan sehari-hari, priayi akan menjadi teladan bagi masyarakat.

Dalam novel Para Priyayi, moralitas priayi dilukiskan melalui tokoh utama, yaitu Sastrodarsono. Sebagai priayi, ia mempunyai tanggung jawab untuk melestarikan kebiasaan yang dijalaninya sebagai priayi. Untuk itu, kepada anak-anaknya ia membiasakan perilaku yang berlaku dalam kebiasaan yang berdasarkan adat atau budaya Jawa. Moralias Sastrodarsono yang bersumber dari budaya Jawa mengajarkan anaknya pasrah dalam menyikapi permasalahan kehidupan. Hal itu diwujudkan oleh anak Sastrodarsono, yaitu Noegroho dalam menyikapi kematian anaknya, Toni, yang tertembak Belanda. Meskipun Toni, anak kesayangannya, telah meninggal dunia, ia mengajak keluarganya untuk tidak bersedih dengan cara mengembalikan peristiwa itu kepada Tuhan, seperti dilukiskan berikut ini.

"Jouw zoon Pak, jouw zoon! Piye anakmu, Pak"

Iya,m iya, Bu. Sing sabar ya, Bu. Ikhlas, Bu, kita ikhlaskan anak kita pergi ya, Bu.

Kalian juga ya, Marie dan Tommi, ikhlaskan kamasmu pergi."

"Sudah, sudah, Bu, ingat. Sing tawakal, Bu. Kita manusia hanya sekadar dititipi Gusti Allah anak-anak kita. Kalau dia mau mengambil kembali, Dia akan mengambil kembali. Dan pasti itu untuk alasan yang baik. Pasti itu untuk kebaikan Toni juga.” (Kayam, 1990:204)

Ajakan kepasrahan Noegroho terhadap keluarganya diperkuat adanya kata sabar, tawakal, dan ikhlas. Kepasrahan itu dapat diterima oleh keluarga Sastrodarsono sehingga Noegroho pun setelah anaknya meninggal bekerja kembali sebagai tentara.

Selain itu, sebagai seorang priayi, Satrodarsono juga menjunjung nilai moral yang bersumber dari budaya Jawa. Ia melakukan kehidupan yang disebut dengan laku, yaitu usaha yang dilakukan dengan penuh keprihatinan. Laku itu dijalani agar tujuan yang akan dicapai dapat terwujud. Laku itu dijalani dengan, misalnya, mengurangi makan atau tidur, berpuasa ngrowot, yaitu hanya makan ketela, jagung atau ubi-ubian yang direbus tanpa garam, dan mutih, yaitu membatasi makan nasi putih tanpa lauk dan tanpa garam.

Dalam peristiwa lain perilaku Sastrodarsono konsisten dengan nilai yang bersumber dari budaya Jawa. Sebagai priayi, ia memaknai hajat besar, seperti perkawinan, sebagai rangkaian hidup yang harus diupacari secara meriah karena kewibawaan priayi juga ditentukan oleh cara menyikapi peristiwa perkawinan. Kemeriahan pesta perkawinan merupakan ukuran kewibawaan priayi. Sastrodarsono saat menikah dengan istrinya, Siti Aisah, juga diupacarai dengan mewah. Dengan demikian, saat Noegroho akan menikahkan anaknya, Marie, Sastrodarsono meminta agar perkawinan cucunya itu diselenggarakan dengan mewah sesuai dengan statusnya sebagai priayi, seperti dilukiskan sebagai beriku. 
"Noegroho, Le, dan kamu Nduk Sus. Kalian akan segera punya kerja keras mengawinkan anakmu, Marie, cucuku yang pertama akan menikah. Laksanakan semua itu dengan hati-hati dan penuh harga diri. Sing sembodo, bersikaplah gagah dalam melaksanakan kerja. Saya tidak dapat hadir karena rasanya tubuh saya tidak akan cukup kuat melakukan perjalanan jauh. Saya beri pangestu kalian berdua." (Kayam, 1990:246-247)

Pesan istri Sastrodarsono itu pun dilaksanakan dengan sungguh-sungguh karena kemewahan itu melambangkan status sosialnya sebagai priayi, seperti dilukiskan berikut ini.

Resepsi pada malam harinya di Hotel Duta Indonesia merupakan puncak perayaaan perkawinan itu. Pakde Noeg seakan mengerahkan semua kemampuan dan gengsinya untuk membuat pesta itu benarbenar nampak wah! Ada kuarng lebih lima ratus undangan diedarkan. Itu berarti ada kurang lebih seribu tamu datang memenuhi ruangan resepsi hotel itu. Sebuah band, serombongan karawitan Jawa, satu kelompok penari Jawa didatangkan untuk membuat suasana semarak. Begitu pula, hidangan mewah yang melimpah ruah dijajar di meja-meja besar tanpa berhenti dikitari tamu-tamu. (Kayam, 1990:255)

\section{Moralitas sebagai Seorang yang Sukses}

Sukses adalah keadaan seseorang yang lebih baik dari sebelumnya. Semua orang selalu megharapkan kesuksesan dalam hidupnya. Meskipun demikian, kesuksesan sering membuat banyak orang lupa diri sehingga orang tersebut dapat berubah menjadi sombong atau kikir. Bagi orang yang menyadari bahwa kesuksesan itu tidak lepas dari kuasa Allah swt., orang itu akan mensyukuri apa yang telah diperolehnya itu. Keadaan seperti itu yang akan menjadikan seseorang berperilaku lebih baik, seperti tidak kikir atau tidak sombong.

Dalam Para Priyayi, moralitas Sastrodarsono setelah menjadi priayi dan kehidupannya berkecukupan tidak membuat dirinya sombong atau kikir. Kesuksesannya tersebut justru menyadarkan dirinya bahwa ia mempunyai kewajiban membantu atau menolong saudaranya yang memerlukan bantuan. Hal itu dilakukan Sastrodarsono dengan menampung saudara dari pihaknya dan saudara dari pihak istri. Dengan demikian, Sastrodarsono selain menghidupi keluarganya juga menghidupi saudaranya. Mereka dididik dan dihidupi seperti anaknya sendiri. Saudara mereka itu berjumlah empat orang, yaitu Ngadimin dan Soenandar (saudara dari Sastrodarsono) serta Sri dan Darmin (saudara dari istri Sastrodarsono). Hal itu dilukiskan sebagai berikut.

Dalam perkembangan keluarga kami, kami tidak hanya berhenti dengan membatasi jumlah anggota keluarga itu dengan anak-anak kami yang tiga orang saja. Untuk itu, kami adalah priayi Jawa, bahkan petani Jawa, yang tidak pernah akan tega dan puas menikmati dan makan rezeki kami hanya oleh keluarga pokok kami saja. Orang tua saya, orang tua Dik Ngasiah selalu saja menekankan hal ini. Karena itu, meskipun saya adalah anak tunggal dan demikian juga Dik Ngasiah, di rumah kami dulu kami tidak pernah merasa kesepian karena selalu ada saja keluarga jauh yang tinggal di rumah kami. Demikian juga sekarang di rumah kami di Wanagalih. Ngadiman, anak dari sepupu saya, jadi cucu dari paman saya, dititipkan orang tuanya kepada saya untuk disekolahkan di HIS. Begitu juga beberapa kemenakan lain, baik dari pihak saya maupun dari pihak Dik Ngasiah, seperti Soenandar, Sri, dan Darmin, pada rame-rame nunjukkan dititipkan orang tua mereka kepada kami. (Kayam, 1999:69-70)

Apa yang telah dilakukan oleh Sastrodarsono itu juga tidak lepas dari pendidikan orang tuanya karena orang tua Sastrodarsono juga melakukan hal yang sama. Moralitas Sastrodarsono yang tidak lupa diri atas kesuksesannya juga ditunjukkan dengan perilakunya yang menghormati orang tuanya dengan tidak melupakan asal usulnya. Sebelum menjadi priayi, Sastrodarsono hidup dalam 
lingkungan petani. Bagi orang tuanya, perubahan Sastrodarsono menjadi priayi dikhawatirkan akan melupakan asal usulnya. Untuk itu, orang tuanya mengingatkan agar Sastrodarsono tidak melupakan asal usulnya sebagai petani. Sebagai rasa hormatnya kepada orang tuanya, Sastrodarsono menuruti harapan orang tuanya. Hal itu ditunjukkan dengan sikap Sastrodarsono dengan tetap bertani meskipun sudah menjadi seorang priayi, seperti dilukiskan sebagai berikut. Adapun rumah tangga yang kami inginkan itu adalah sudah tentu rumah tangga priayi. Priayi muda yang kepalanya mendongkrak ke atas jenjang-jenjang tangga kemajuan. Akan tetapi, bagaimanapun, naluri petani saya, bahkan juga Dik Ngasiah, masih hadir juga dalam kami. Tegalan dan sawah di belakang rumah tidak kami bagi hasilkan seperti dulu Romo Seten membagihasilkan sawahnya dengan bapak saya. Kami memilih menggaji buruh-buruh sawah dengan membayar mereka sebagian dengan uang, sebagian dengan bawon, ikatan padi waktu panenan. Sedikit-sedikit saya masih tahu juga cara orang bertani, ditambah pula dengan kedatangan Bapak serta Paman untuk membantu membuka tegalan dan sawah hujan itu. Mereka menganjurkan agar tegalan ditanami segala macam ubi-ubian, berbagai jenis pisang, serta berbagai tanaman untuk bumbu dapur. Sedang untuk sawah, karena sawah tadah hujan ya hanya macam padi gogo saja yang dapat ditanam. (Kayam, 1990:48)

Kutipan rersebut menjelaskan bahwa Sastrodarsono tidak meninggalkan asal usulnya sebagai petani meskipun Sastrodarsono telah menjadi priayi. Namun, cara bertani yang dilakukannya berbeda dengan cara bertani yang dilakukan oleh orang tuanya. Cara bertani Sastrodarsono tidak dikerjakan sendiri, tetapi dilakukan dengan menggaji buruh. Sementara itu, cara bertani orang tuanya dikerjakan sendiri.

Sastrodarsono juga menanamkan sikap hormat kepada anak-anaknya. Salah satu anaknya, Noegroho, meskipun telah mempunyai kedudukan tinggi di kantornya, di hadapan orang tuanya ia tetap berlaku sebagai anak yang tetap membutuhkan nasihat orang tuanya. Setiap nasihat yang diberikan Sastrodarsono akan dipatuhi oleh Noegroho, seperti dilukiskan sebagai berikut.

.... Betapapun kami sudah menjadi orang, sudah beranak pinak, dan memiliki kedudukan di masyarakat. Orang tua saya, terutama Bapak, adalah matahari tempat kami berpaling. Seperti juga matahari, Bapak memang selalu menyilaukan mata kami. Di hadapannya kami anak-anak masih tetap anak-anak. Dari mulutnya keluar sabda-sabda yang mengandung bobot yang berwibawa sekali bagi kami anak-anak. Kami menerima sabda atau fatwa itu tanpa reserve, tanpa berani menyanggahnya. (Kayam, 1990:180 - 181)

\section{SIMPULAN}

Karya sastra diciptakan pengarang karena pengarang ingin menyampaikan nilai yang dilihat dan dialami di lingkungan tempat ia berada. Dari nilai itu, moralitas hadir. Moralitas itu diwujudkan dalam karya sastra melalui tokoh dan peristiwa yang melibatkan tokoh, yaitu dengan berbuat atau tidak berbuat menurut moral atau menurut tuntunan moralitas yang diyakininya.

Novel Para Priyayi karya Umar Kayam dapat digali aspek moralitasnya melalui tokoh-tokohnya. Dalam penelitian ini yang menjadi fokus utama adalah moralitas tokoh utamanya, yaitu Sastrodarsono. Dari hasil analisis dapat disimpulkan bahwa moralitas tokoh Sastrodarsono yang menonjol adalah moralitas sebagai kepala keluarga, moralitas sebagai guru atau pendidik, moralitas sebagai pemangku budaya, dan moralitas sebagai seorang yang sukses. 
Moralitas Sastrodarson sebagai kepala keluarga ditunjukkan perilakunya dengan memberikan pendikan kepada anak-anaknya guna melanjutkan kepriayiannya. Moralitas Sastrodarsono sebagai guru ditunjukkan dengan sikap pengabdiannya sebagai guru yang baik dengan cara menerapkan disiplin kepada muridnya dalam belajar dan menjaga kewibawaan negaranya dari penjajah Jepang. Moralitas Sastrodarsono sebagai pemangku budaya ditunjukkan dengan perilakunya yang berdasarkan budaya Jawa, yaitu dengan sikap pasrah dan hidup prihatin. Moralitas Sastrodarsono sebagai seorang yang sukses ditunjukkan dengan sikapnya yang tidak sombong dan tidak melupakan asal usulnya sebagai seorang petani. 


\section{DAFTAR PUSTAKA}

Abrams, M.H. 1981. The Mirrow and the Lamp. London: Oxford University Press.

Bertens, Kees. 2002. Etika. Jakarta: Gramedia Pustaka Utama.

Damono, Sapardi Djoko. 1984. Sosiologi Sastra: Sebuah Pengantar Ringkas. Jakarta: Pusat Pembinaan dan Pengembangan Bahasa, Departemen Pedidikan dan Kebudayaan.

Darma, Budi. 1984. "Moral dan Sastra” Dalam Budaya Sastra. Jakarta: Rajawali Press.

Fananie, Zainuddin. 2002. Telaah Sastra. Surakarta: Muhammadiyah University Press.

Junus, Umar. 1986. Sosiologi Sastra: Persolan Teori dan Metode. Kualalumpur: Dewan Bahasa dan Pustaka.

Kayam, Umar. 1990. Para Priyayi. Jakarta: Grafiti.

Keraf, Sonny. 1991. Etika Bisnis. Yogyakarta: Kanisius.

Nawawi, Hadawi. 2012. Metode Penelitian Bidang Sosial. Jakarta: Sinar Harapan.

Nurgiantoro, Burhan. 2005. Teori Pengkajian Fiksi. Yogyakarta: Gadjah Mada University Press.

Poedjawijatna. 1996. Etika Filsafat Tingkah Laku. Jakarta: Rineke Cipta.

Pradopo, Rachmat Djoko. 2012. Pengkajian Puisi. Yogyakarta: Gadjah Mada University Press.

Pusat Pembinaan dan Pengembangan Bahasa. 2008. Kamus Besar Bahasa Indonesia. Jakarta: Gramedia.

Ratna, Nyoman Kutha. 2008. Teori, Metode, dan Teknik Penelitian Sastra. Yogyakarta:Pustaka Pelajar

Sardiman. 2011. Interaksi danMotivasi Bajar Mengajar. Jakarta: Rajawali Press.

Solomon, Robert C. 1987. Etika Suatu Pengantar.Terjemahan. R. Andra Karo. Jakarta: Erlangga.

Teeuw, A. 1983. Pengantar Ilmu Sastra. Jakarta: Gramedia.

Velazquez, Manuel G. 2005. Etika Bisnis: Konsep dan Kasus. Terjemahan. Business Ethics, Concepts and Cases (2002). Ana Purwaningsih, dkk. Yogyakarta: ANDI. 
Wellek, Rene dan Austin Warren. 1989. Teori Kesusasteraan. Terjemahan Theory of Literature. Melani Budianta. Jakarta: Gramedia. 